\title{
An assessment of adaptive and antagonistic properties of Trichoderma sp. strains in vegetable waste composts
}

\author{
Agnieszka Wolna-Maruwka ${ }^{1 *}$, Tomasz Piechota ${ }^{2}$, Alicja Niewiadomska ${ }^{1}$, Jacek Dach ${ }^{3}$, \\ Magdalena Szczech ${ }^{4}$, Małgorzata Jędryczka ${ }^{5}$, Agnieszka A. Pilarska ${ }^{6}$
}

Poznan University of Life Sciences, Poland

${ }^{1}$ Department of General and Environmental Microbiology

${ }^{2}$ Department of Agronomy

${ }^{3}$ Instytute of Biosystems Engineering

${ }^{4}$ Research Institute of Horticulture in Skierniewice, Poland

${ }^{5}$ Institute of Plant Genetics, Polish Academy of Sciences, Poland

${ }^{6}$ Institute of Food Technology of Plant Origin, Poland

*Corresponding author's e-mail: amaruwka@up.poznan.pl

Keywords: moulds, compost, interaction, Trichoderma.

\begin{abstract}
The experiment consisted in monitoring the count of moulds and three selected Trichoderma sp. isolates (T1 - Trichoderma atroviride, T2 - Trichoderma harzianum, T3 - Trichoderma harzianum) in vegetable (onion and tomato) waste composted with additives (straw, pig manure). Additionally, the aim of the study was to determine the type of interaction occurring between autochthonous fungi isolated from composts after the end of the thermophilic phase and Trichoderma sp. strains applied in the experiment. Number of microorganisms was determined by the plate method, next the identification was confirmed. The rating scale developed by Mańka was used to determine the type of interactions occurring between microorganisms.

The greatest count of moulds in onion waste composts was noted in the object which had simultaneously been inoculated with two strains $\mathrm{T} 1-T$. atroviride and $\mathrm{T} 3-T$. harzianum. The greatest count of moulds was noted in the tomato waste composts inoculated with T2 $-T$. harzianum strain. Microscope identification revealed that Penicillum sp., Rhizopus sp., Alternaria sp. and Mucor sp. strains were predominant in onion waste composts. In tomato waste composts Penicillium was the predominant genus, followed by Rhizopus. The test of antagonism revealed the inhibitory effect of Trichoderma isolates on most autochthonous strains of moulds.

Tomato waste composts proved to be better substrates for the growth and development of Trichoderma sp. isolates. The results of the study show that vegetable waste can be used in agriculture as carriers of antagonistic microorganisms.
\end{abstract}

\section{Introduction}

One of major trends in handling waste and using it for energy purposes is to concentrate on reducing the amount of vegetable waste composts produced and on recycling it appropriately (Malińska et al. 2014).

According to Sołowiej (2007), agricultural production results in considerable amounts of waste, such as damaged or unused parts of plants, which often makes even as much as $20 \%$ of yield.

Onions (Allium cepa L.) are the second most important horticultural crop worldwide, after tomatoes. Over the past 10 years, onion production has increased by more than $25 \%$. Accordingly, more than 500.000 tonnes of onion waste is produced annually in the European Union, mainly in Spain, the UK and Holland (FAO Statistics 2008).
In Poland there are numerous legal regulations which indicate that bioprocessing is a preferable method of handling biodegradable waste. For example, according to Council Directive 1999/31/EC, in 2020 Poland will have to reduce the amount of landfilled biodegradable communal waste by $65 \%$. This legal act is an enormous challenge because landfilling is an essential method of handling waste in Poland (EU Council Directive 1999). Unprocessed waste is usually stored, which is a threat to the purity of underground and surface waters. According to Rosolak and Gworek (2006), landfills are environmentally unfriendly as they pollute the atmosphere with dust, gases, bacteria, odours and methane. They also attract birds and rodents.

Composting seems to be an effective and economical method of handling vegetable waste. This process gives a sanitarily safe product, which is highly useful as a fertiliser 
and meets the requirements of the Regulation of the Minister of the Environment on R10 recovery, issued on 20 January 2015 (Regulation of the Minister of the Environment 2015, WolnaMaruwka et al. 2015).

The compost can be a perfect carrier for microorganisms promoting the growth and development of plants, such as fungi of the Trichoderma sp. genus (Smolińska et al. 2014), which undergo adsorption and overgrow composted organic matter. When they are entered into soil, they have a better chance to survive confrontation with the autochthonous soil microflora.

The use of such an innovative product, consisting of composted organic matter inoculated with strains of Trichoderma sp., for cultivation of selected plants strictly follows the current agricultural policy of Poland. On 1 January 2014 obligatory integrated plant protection was introduced in the EU countries. In Poland it was introduced in the Crop Protection Products Act (2013). According to the Act, integrated plant protection is a method of protecting plants from harmful organisms, which consists in using all plant protection methods available, especially non-chemical methods, minimising the health hazard to humans, animals and the environment.

There is a wide range of scientific reports proving the positive effect of Trichoderma sp. strains in promoting the growth and development of crops (Harman et al. 2004, Bal and Altintas 2006).

According to Szczech et al. (2008), fertiliser preparations containing Trichoderma sp. fungi are not common in the Polish market. Howell (2003) recommends that strains of active groups of microorganisms which are to be used as preparations should be acquired from the regions where they will be applied. It will ensure their quick adaptation to the soil environment and positive effect on the growth of plants.

The aim of the study was to assess the antagonistic properties of three strains of Trichoderma sp. on the autochthonous microflora in composts and to determine their adaptability to onion and tomato waste composts to be used for vegetable growing.

\section{Material and methods}

\section{Experimental design}

A composting experiment was set up in a field in spring 2013 and 2014. Tomato waste from greenhouse production, onion waste from mechanical peeling, wheat straw and pig manure were used in the study.

Composts used in the experiment were produced on a technical scale (in prisms with a capacity of about 20 tonnes). Tomato waste compost (mostly racemes and leaves) and onion waste compost (peel, rotten and small onions, etc.) was mixed with wheat straw (about 10\%) and 5\% of manure. The material was composted in prisms for about 6-7 weeks. When the thermophilic phase ended (prism temperature-about $25^{\circ} \mathrm{C}$ ), each prism was divided into 3 parts (with two replicates). Samples for microbial analyses were collected and the prisms were inoculated with three strains of Trichoderma sp. (T1 - T. atroviride, T2 -T. harzianum, T3-T. harzianum), which came from the collection of strains of the Institute of Horticulture in Skierniewice, Poland. An in vitro test had been conducted prior to inoculation to exclude the antagonistic effect of Trichoderma isolates applied in the experiment (Mańka 1974).
In order to prepare a spore suspension for inoculation of composts, isolates were proliferated on a solid PDA medium (Sigma Aldrich). After seven-day incubation at a temperature of $24^{\circ} \mathrm{C}$ the cultured Trichoderma sp. were scraped off with a sterile scalpel and suspended in sterile distilled water $(500 \mathrm{ml})$. The suspension was homogenised in a laboratory mixer, which enabled separation of conidial spores from hyphae. The output concentration of individual spores in the obtained suspension was measured by means of a haemocytometer under a light microscope (Zeiss). The following results were noted: strain T1 $-2.9 \cdot 10^{9}, \mathrm{~T} 2-2.4 \cdot 10^{9}, \mathrm{~T} 3-3.0 \cdot 10^{9}$ per $1 \mathrm{ml}$. The composts were inoculated with a suspension of conidial spores concentrated at $10^{4}$ per g w.m. of compost. Therefore, after calculation each prism of the composted material was respectively inoculated with $68.96 \mathrm{ml}$ of T1 strain spore suspension, $83.33 \mathrm{ml}$ of T2 isolate, $66.60 \mathrm{ml}$ of $\mathrm{T} 3$ strain, $76.14 \mathrm{ml}$ of a T1+T2 mixture and $67.78 \mathrm{ml} \mathrm{a} \mathrm{T1+T3}$ strain suspension. These conidial spore suspensions were mixed in 51 of dechlorinated tap water and applied with a hand sprayer.

The following six combinations were used in the experiment:

TT1 - tomato waste compost inoculated with strain T1

TT2 - tomato waste compost inoculated with strain T2

$\mathrm{TT} 1+\mathrm{T} 2$ - tomato waste compost inoculated with strains $\mathrm{T} 1$ and $\mathrm{T} 2$

OT1 - onion waste compost inoculated with strain T1

OT3 - onion waste compost inoculated with strain T3

OT1+T3 - onion waste compost inoculated with strains $\mathrm{T} 1$ and $\mathrm{T} 3$

The experiment with compost inoculation with Trichoderma sp. strains was replicated twice, in spring 2013 and 2014.

Compost samples for microbial analyses were collected twice: one month and two months after the inoculation.

\section{Microbiological analysis}

The scope of experiments comprised determination (in five replications) of the total count of moulds and Trichoderma sp. The groups of microorganisms were cultured according to the plate method on solid substrates, using appropriate dilutions of soil solutions, expressed as $\mathrm{CFU} \cdot \mathrm{g}^{-1}$ of soil dry matter.

The count of moulds was determined on a medium prepared according to Martin (1950) with rose bengal and aureomycin added. Plates were incubated for 6 days at a temperature of $25^{\circ} \mathrm{C}$. Colonies of moulds isolated from composts at the end of the thermophilic phase were inoculated to a PDA substrate (Sigma Aldrich) on the day of their inoculation with Trichoderma sp. isolates. Next, their systematic position was determined according to mycological keys and the percentage of individual genera in the entire population was calculated (Domsch et al. 1993).

The count of Trichoderma sp. strains was determined with the plate method, on a modified Martin's medium (Martin 1950) with chloramphenicol, streptomycin, metalaxyl and PCNB (pentachloronitrobenzene) added. The plates were exposed to visible light and incubated for 7 days at a temperature of $24^{\circ} \mathrm{C}$. In order to confirm the systematic position of Trichoderma sp. in the Trichoderma harzianum or Trichoderma atroviride species the colonies were inoculated to the PDA substrate (Sigma Aldrich). They were initially identified with a microscope. Next, the identification 
was confirmed by means of in situ hybridisation (FISH), modified according to Amann et al. (1990), where 4\% PFA (paraformaldehyde), $0.5 \%$ Triton solution, alcohol series $(70 \%, 80 \%, 96 \%), 70 \%$ formamide solution and two probes, marked at end 3' with marker Cy3 (ACT CCC AAA CCC AAT GTG AA and ATA CCA AAC TGT TGC CTCGG) were applied (Siddiquee et al. 2010) (Figure 1).

The rating scale developed by Mańka (1974) was used to determine the type of interactions occurring between strains of autochthonous moulds isolated from the composts at the end of the thermophilic phase and Trichoderma sp. isolated applied in the research. The following factors were taken into consideration: the degree to which one colony surrounded another, the width of the inhibitory zone and growth inhibition. A positive result should be interpreted as an effect limiting the development of a particular autochthon (test fungus) by a selected Trichoderma sp. isolate (antagonist).

Before the experiment was set up, fungi had been proliferated on a PDA medium. Next, a sterile cork borer was used to cut discs of cultures (10 $\mathrm{mm}$ in diameter). The discs were transferred to the PDA medium and spaced at $30 \mathrm{~mm}$ from each other. Every day, for 8 days the mycelium diameter was measured in the dual-organism cultures and the type of interaction between the fungi was determined. The cultures were incubated at a temperature of $24^{\circ} \mathrm{C}$. Single-organism cultures prepared in an analogical manner were used as control samples. All tests were replicated five times.

\section{Chemical analysis}

The chemical analysis of composts was conducted in the laboratory of the Department of Agronomy. The content of carbon was determined with the Tiurin method. The content of total nitrogen in the fresh weight of composts was measured with the Kjeldahl method by means of a Kjeltec 2200 System analyser (FOSS Tecator). The $\mathrm{pH}$ values of compost samples were determined in double distilled water. $\left(\mathrm{pH}_{\mathrm{H} 2 \mathrm{O}}\right)$. The content of dry weight of composts was measured by drying and weighing at a temperature of $105^{\circ} \mathrm{C}$ in the laboratory of the Institute of Biosystem Engineering.

\section{Statistical analysis}

Statistical analyses were conducted by means of Statistica 12.0 software (StatSoft Inc. 2012). Two-way analysis of variance was used to determine the significance of variation in the number of moulds under analysis, depending on the

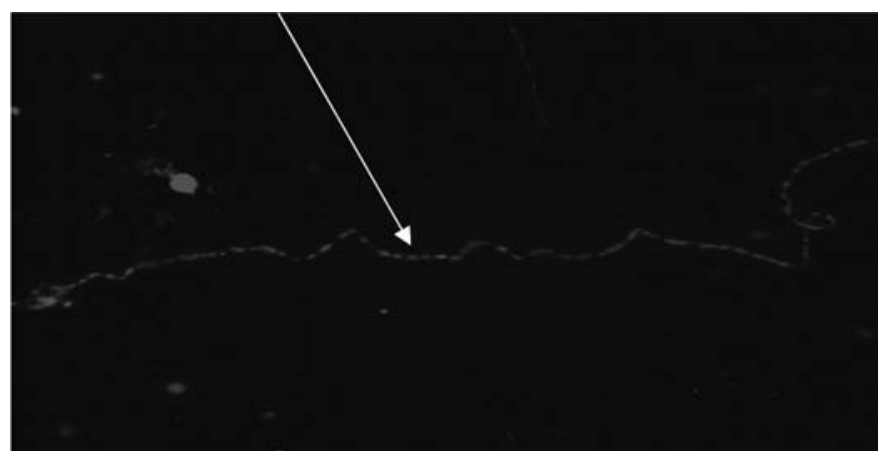

Fig. 1. Specific identification of whole fixed Trichoderma harzianum fungal hyphae with fluorescent oligonucleotide probes (FISH) compost combination and term of analysis. Homogeneous subsets of means were identified by means of Tukey's test at a significance level of $p=0.05$.

Principal Component Analysis (PCA) was used to illustrate the dependence between the number of microorganisms and chemical parameters of compost.

\section{Results and discussion}

The research was supposed to determine the possibility to use vegetable waste composts as substrates for the growth and development of fungi of the Trichoderma genus, which could be used for plant cultivation due to their phytosanitary and plant growth promoting properties (Bal and Altintas 2006).

Onion and tomato waste composts were used as carriers for three strains of Trichoderma sp. The decision about the choice of waste subjected to composting and inoculated with Trichoderma sp. isolates was influenced by the availability of waste because only the waste which is produced in large amounts can be used in agriculture.

Waste which is to be used as a substrate for microorganisms must be characterised by adequate chemical parameters (Smolińska et al. 2014) to guarantee optimal growth and development of microorganisms.

The analysis of chemical properties of the composts used in the experiments (Table 1) showed that the humidity in the combinations under study was similar and there were no statistically significant differences at $p=0.05$ at a particular term of measurement. The comparison of $\mathrm{pH}$ values of the composts in both experiments resulted in analogical observations. Apart from that, regardless of the type of experiment and compost, at the second term of analyses there was a statistically insignificant increase in the $\mathrm{pH}$ values in the combinations, which was most likely the effect of the application of Trichoderma sp. isolates.

This thesis is confirmed by findings made by Yedidia et al. (2001). As the authors observed, fungi of the Trichoderma sp. genus may increase the $\mathrm{pH}$ value of the substrate through the secretion of enzymes, such as cellulases, pectinases, xylanases and proteases. The study by Howell (2003) also confirmed that the enzymatic activity of Trichoderma sp. increased the $\mathrm{pH}$ of the substrate.

The analysis of the growth and development of moulds applied to the composts in experiment no. I revealed that in most cases the count of the moulds was increasing in a statistically significant way, i.e. at $p=0.05$ (Figures 2 and 3), as the experiment was progressing. The mycological assessment of the composts in experiment II showed a statistically significant decrease in the count of these microorganisms in most of the variants. The statistically significant increase in the proliferation of moulds in the composts at the end term of analyses (experiment I) arouses some controversy, because in general fungi prefer acidic or neutral $\mathrm{pH}$ of the substrate, whereas the $\mathrm{pH}$ value of the composts varied from 8.45 to 8.91 .

However, as results from the study by Skowron et al. (2011), moulds also exhibit tolerance to alkaline $\mathrm{pH}$. The authors observed that the count of these microorganisms reached the order of $1.50 \cdot 10^{4} \mathrm{CFU}$ in composted sewage sludge when the $\mathrm{pH}$ value was 8.40 .

The principal component analysis (PCA) did not confirm the influence of the $\mathrm{pH}$ value on the dynamics of growth of moulds either in the tomato composts or in the onion ones 
(Figure 4). However, it proved the positive dependence between the count of moulds and humidity of compost combinations.

Compost humidity is a basic parameter influencing normal development of microorganisms. According to Malińska et al. (2014), in a mature compost it should amount to $50-60 \%$.
The analysis of the count of moulds in the onion waste composts showed that when the experiment finished, both in the first and second experiment the greatest count of moulds was observed in the combination which had simultaneously been inoculated with two Trichoderma strains T1 and T3. As

Table 1. Properties of composts used in experiments

\begin{tabular}{|c|c|c|c|c|c|c|}
\hline \multirow{2}{*}{ Properties } & \multicolumn{6}{|c|}{ Kind of compost } \\
\hline & TT1 & TT2 & $\mathrm{TT} 1+\mathrm{T} 2$ & OT1 & OT3 & OT1+T3 \\
\hline \multicolumn{7}{|c|}{$\begin{array}{c}\text { Experiment I } \\
1 \text { month after inoculation }\end{array}$} \\
\hline $\mathrm{pH}_{\mathrm{H} 2 \mathrm{O}}$ value & $8.01^{\mathrm{ns}}$ & $8.18^{\mathrm{ns}}$ & $7.99^{\mathrm{ns}}$ & $8.24^{\mathrm{ns}}$ & $8.34^{\mathrm{ns}}$ & $8.17^{\mathrm{ns}}$ \\
\hline $\begin{array}{l}\text { humidity } \\
\text { (\%) }\end{array}$ & $45.19^{a b}$ & $45.43^{a b}$ & $47.88^{a-f}$ & $47.56^{a-f}$ & $46.45^{a-f}$ & $49.34^{d-f}$ \\
\hline \multicolumn{7}{|c|}{$\begin{array}{c}\text { Experiment I } \\
2 \text { months after inoculation }\end{array}$} \\
\hline $\mathrm{pH}_{\mathrm{H} 2 \mathrm{O}}$ value & $8.78^{\mathrm{ns}}$ & $8.47^{\mathrm{ns}}$ & $8.76^{\mathrm{ns}}$ & $8.91^{\mathrm{ns}}$ & $8.45^{\mathrm{ns}}$ & $8.67^{\mathrm{ns}}$ \\
\hline $\begin{array}{l}\text { humidity } \\
(\%)\end{array}$ & $54.36^{\mathrm{h}}$ & $59.65^{g}$ & 50.98 ef & 50.71 ef & $48.11^{a-f}$ & $54.66^{g}$ \\
\hline \multicolumn{7}{|c|}{$\begin{array}{c}\text { Experiment II } \\
1 \text { month after inoculation }\end{array}$} \\
\hline $\mathrm{pH}_{\mathrm{H} 2 \mathrm{O}}$ value & $8.18^{\mathrm{ns}}$ & $8.14^{\mathrm{ns}}$ & $8.34^{\mathrm{ns}}$ & $8.19^{\mathrm{ns}}$ & $8.26^{\mathrm{ns}}$ & $8.35^{\mathrm{ns}}$ \\
\hline $\begin{array}{l}\text { humidity } \\
(\%)\end{array}$ & $44.78^{a}$ & $47.56^{\mathrm{a}-\mathrm{e}}$ & $45.90^{a-c}$ & $50.67^{\text {ef }}$ & $49.56^{d-f}$ & $45.89^{a-c}$ \\
\hline \multicolumn{7}{|c|}{$\begin{array}{c}\text { Experiment II } \\
2 \text { months after inoculation }\end{array}$} \\
\hline $\mathrm{pH}_{\mathrm{H} 2 \mathrm{O}}$ value & $8.41^{\mathrm{ns}}$ & $8.58^{\mathrm{ns}}$ & $8.77^{\mathrm{ns}}$ & $8.74^{\text {ns }}$ & $8.99^{n s}$ & $8.67^{\text {ns }}$ \\
\hline $\begin{array}{l}\text { humidity } \\
(\%)\end{array}$ & $47.99^{c-f}$ & $50.12^{e f}$ & $49.12^{c-f}$ & $55.98^{g}$ & 50.78 ef & $48.32^{b-h}$ \\
\hline
\end{tabular}

Explanation: Means followed by the same letters do not differ significantly at $p=005$;

ns-no significant difference;

Combination: TT1 - tomato waste compost inoculated with strain T1, TT2 - tomato waste compost inoculated with strain T2, TT1+TT2 - tomato waste compost inoculated with strain T1 and T2, OT1 - onion waste compost inoculated with strain T1, OT3 - onion waste compost inoculated with strain T3, OT1+OT3 - onion waste compost inoculated with strain T1 and T3.

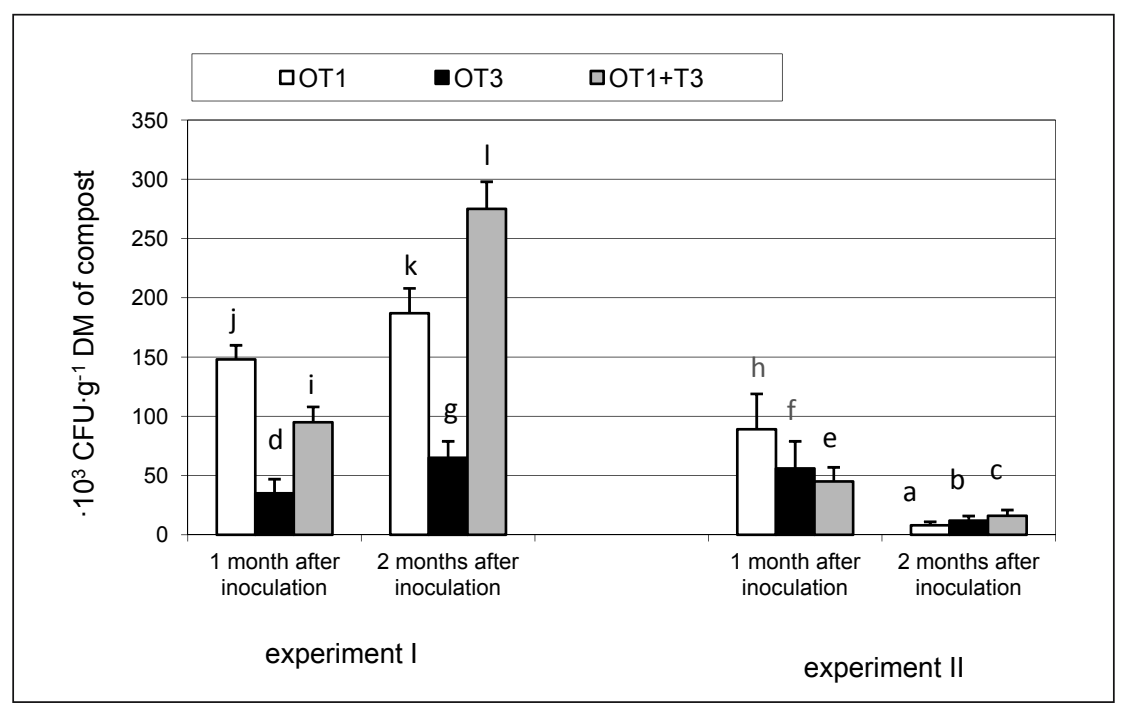

Fig. 2. The changes of total number of moulds in onion composts

Explanation: Means followed by the same letters do not differ significantly at $p=0.05$;

Combination: OT1 - onion waste compost inoculated with strain T1, OT3 - onion waste compost inoculated with strain T3,

OT1+OT3 - onion waste compost inoculated with strain T1 and T3. 


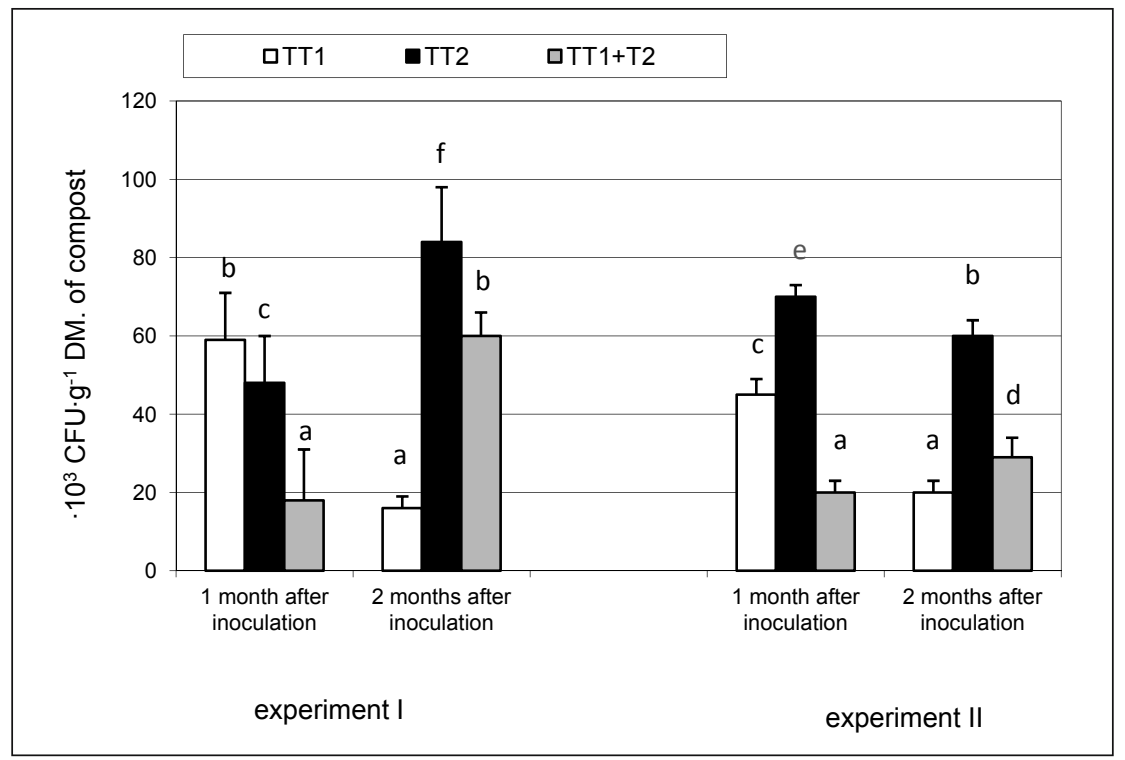

Fig. 3. The changes of total number of moulds in tomato composts

Explanation: Means followed by the same letters do not differ significantly at $p=0.05$;

Combination: TT1 - tomato waste compost inoculated with strain T1, TT2 - tomato waste compost inoculated with strain T2, TT1+TT2 - tomato waste compost inoculated with strain T1 and T2.

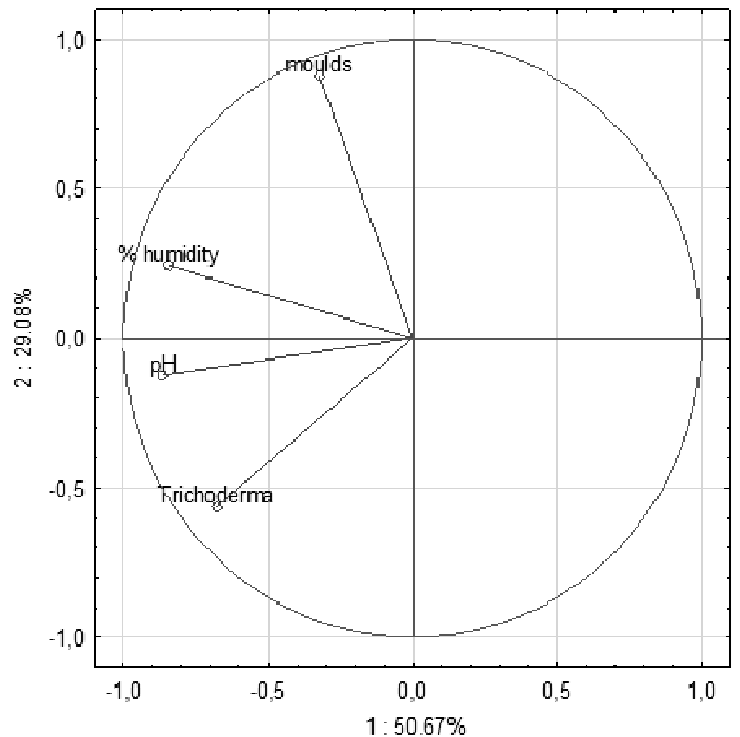

Fig. 4. Dependences between the number of moulds, Trichoderma sp, $\mathrm{pH}$ value and humidity (\%) of applied in the experimental compost combinations at consecutive terms of analyses (PCA)

far as the tomato waste composts are concerned, the greatest count of moulds was noted in the variant inoculated with strain T2.

When we consider the count of moulds in the composts before the inoculation with Trichoderma sp. strains (Table 2), the research proved that regardless of the type of the Trichodema sp. isolate applied to the composts, in most of the experimental variants the inoculation noticeably decreased the total count of moulds (Figures 2 and 3). However, the principal component analysis (PCA), which accounted for a considerable amount of variability (more than 55\%), did not prove that the applied Trichodema sp. isolates had statistically significant influence on limiting the growth and development of the autochthonous moulds in the composts.

The mycological analysis of the experimental variants conducted on the day of inoculation (Tables 3 and 4) proved that regardless of the type of composts, there was the highest percentage of fungi of the Penicillium genus, followed by the Rhizopus and Aspergillus genera. There was the lowest percentage of Alternaria sp. (2-4\%), Paecilomyces variotti (2\%) and Cephalosporium sp. (3\%). Apart from that, the Mucor genus was isolated both from the tomato and onion waste composts, which in both cases amounted to $5 \%$ of the total population of the autochthonous microflora. The analysis of the composition of the moulds in the materials under 
Table 2. The microbiological and chemical state of composts used in experiments (beginning of experiments)

\begin{tabular}{|c|c|c|c|c|c|c|}
\hline Kind of compost & $\begin{array}{c}\text { Total moulds } \\
\text { number } \\
\left(10^{3} \mathrm{cfu} \mathrm{g}^{-1} \mathrm{DM}\right)\end{array}$ & $\begin{array}{l}\text { Trichoderma sp. } \\
\left(10^{2} \mathrm{cfu} \mathrm{g}^{-1} \mathrm{DM}\right)\end{array}$ & $\mathrm{pH}_{\mathrm{H} 2 \mathrm{O}}$ & $\begin{array}{l}\text { humidity } \\
(\%)\end{array}$ & $\begin{array}{c}\mathrm{C} \\
\mathrm{g} \cdot \mathrm{kg}^{-1} \\
\mathrm{DM}\end{array}$ & $\begin{array}{c}\mathrm{N} \\
\mathrm{g} \cdot \mathrm{kg}^{-1} \mathrm{D} \\
\mathrm{M}\end{array}$ \\
\hline \multicolumn{7}{|c|}{ Experiment I } \\
\hline Tomato compost & 100.78 & 2.46 & 7.78 & 40.55 & 344.81 & 17.93 \\
\hline Onion compost & 133.78 & - & 7.99 & 45.89 & 353.80 & 21.73 \\
\hline \multicolumn{7}{|c|}{ Experiment II } \\
\hline Tomato compost & 93.33 & 3.99 & 8.01 & 38.99 & 406.00 & 20.22 \\
\hline Onion compost & 198.45 & - & 7.67 & 41.67 & 447.10 & 23.11 \\
\hline
\end{tabular}

Table 3. Isolates of moulds isolated from the tomato compost

\begin{tabular}{|l|c|}
\hline \multicolumn{1}{|c|}{ Isolate } & Percentage content (\%) \\
\hline Tomato compost - Experiment I & 82 \\
\hline Penicillum sp. & 4 \\
\hline Rhizopus sp. & 14 \\
\hline Trichoderma atroviride & 16 \\
\hline \multicolumn{2}{|c|}{ Tomato compost - Experiment II } \\
\hline Penicillium sp. (1) & 28 \\
\hline Penicillium sp. (2) & 5 \\
\hline Mucor sp. & 30 \\
\hline Rhizopus nigricans & 5 \\
\hline Rhizopus sp. & 16 \\
\hline Trichoderma atroviride & \\
\hline
\end{tabular}

Table 4. Isolates of moulds isolated from the onion compost

\begin{tabular}{|l|c|}
\hline \multicolumn{1}{|c|}{ Isolate } & Percentage content (\%) \\
\hline \multicolumn{2}{|c|}{ Onion compost - Experiment I } \\
\hline Penicillum sp. (1) & 48 \\
\hline Penicillium sp. (2) & 36 \\
\hline Rhizopus sp. & 7 \\
\hline Alternaria sp. & 4 \\
\hline Mucor sp. & 5 \\
\hline & \\
\hline Aspergillus niger & 14 \\
\hline Rhizopus nigricans & 20 \\
\hline Penicillium sp. (1) & 19 \\
\hline Penicillium sp. (2) & 35 \\
\hline Cephalosporium sp. & 3 \\
\hline Paecilomyces variotti & 2 \\
\hline Mucor sp. & 5 \\
\hline Alternaria sp. & 2 \\
\hline
\end{tabular}

study proved that $T$. atroviride (14-16\%) was also isolated from the tomato waste composts. These results confirm the findings made by Wojtkowiak-Gębarowska (2006), who observed common occurrence of Trichoderma in different environments (soil, plants, composts, manure).
Tests for antagonism proved that in both experiments selected Trichoderma sp. strains exhibited comparable antagonistic properties to moulds isolated from the tomato and onion waste composts. According to Dłużniewska (2004), Trichoderma sp. has numerous antagonistic properties. It is 
characterised by rapid growth, abundant sporulation, capacity to exist on many substrates and produce fungitoxic substances, easy use of available organic matter and inorganic compounds as well as parasitic capacity. Apart from that, the capacity of Trichoderma sp. to produce green pigment (Szczech et al. 2008) considerably facilitated estimation of the type of interaction between the antagonist and isolated microflora. This observation was confirmed in our study (Figure 5).

The analysis of the results presented in Tables 5 and 6 revealed that all the Trichoderma strains (T1, T2, T3) used in the experiments exhibited antagonistic properties to most of the moulds isolated from the plant material.

Isolate $\mathrm{T} 1-T$. atroviride was characterised by the strongest biotic effects, which were particularly noticeable in experiment I.

According to Witkowska and Mai (2002), the phytosanitary properties of Trichoderma sp. result from the production of volatile and non-volatile compounds, where stronger effect is attributed to non-volatile secondary metabolites (enzymes and antibiotics). Also, according to Busko et al. (2008) and Howell (2003), fungi of the Trichoderma sp. owe their phytosanitary properties to antibiotics and antimetabolites (alamethicin, tricholine, peptaibols, viridine, gliovirin, gliotoxin, glisoprenin, heptelidic acid, $\alpha$-pyrrole) and enzymes (cellulase, hemicellulase, xylanase, pectinase, $\beta$-1,3-glucanase, chitinase and protease), which degrade the mycelium.

According to Perek et al. (2013), combined activity of enzymes and antibiotics produced by microorganisms may result in greater antagonism than the individual effect of antibiotics or enzymes. Initial degradation of the cell wall by enzymes may facilitate penetration of antibiotics into the cells of other microorganisms.

In our study Trichoderma strains exhibited the weakest antagonism to Mucor sp. and Rhizopus sp. isolates as well as some of Penicillium sp. strains.

According to Piegza el al. (2009), weaker inhibitory properties of fungi of the Trichoderma genus may be caused

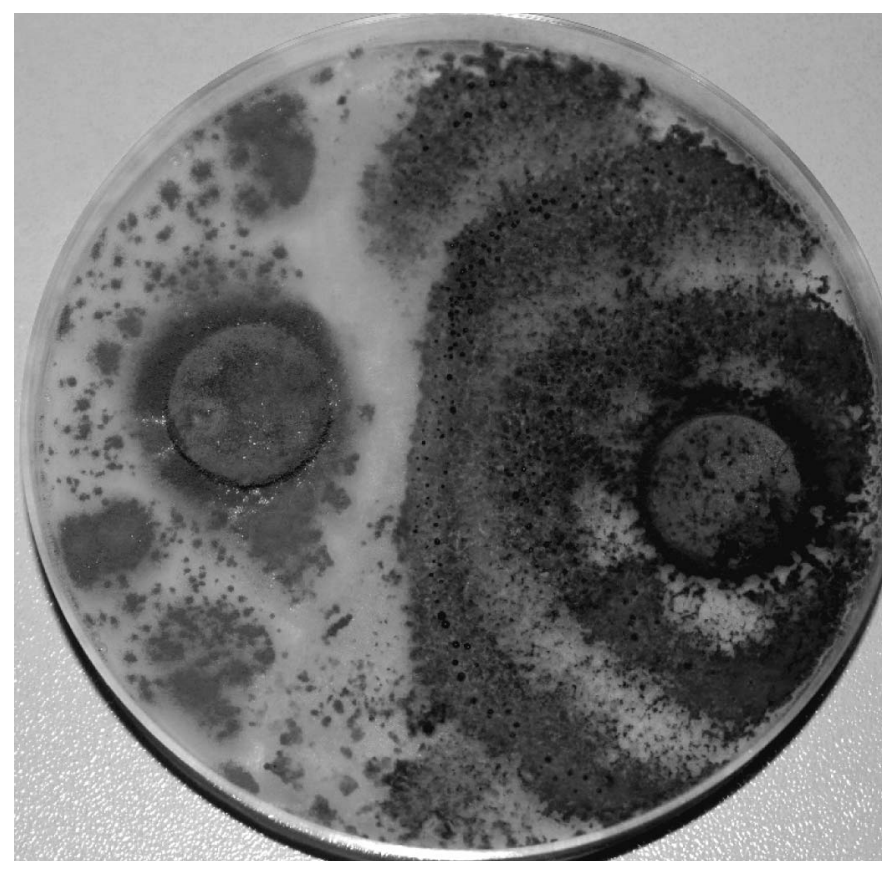

Fig. 5. Relationship between Penicillium sp. (2) isolate and Trichoderma harzianum - T3 by their weaker capacity to compete for food or place of colonisation, slower growth on a plate and poorer sporulation of Trichoderma isolates. In consequence, they are not capable of complete colonisation of space.

Apart from that, Wawrzyniak and Waśkiewicz (2014) proved that some Penicillium species were able to produce antibiotics and mycotoxins, such as ochratoxin A and citrinin. According to the authors, these metabolites produced by some Penicillium strains have toxic effect on other microorganisms, including Trichoderma.

During the experiment, the count of Trichoderma sp. remained at $10^{2} \mathrm{CFU} \mathrm{g}{ }^{-1} \mathrm{DM}$, regardless of the compost type (Figures 6 and 7). All Trichoderma strains were applied to the composts at a conidia concentration of $10^{4} \mathrm{~g}^{-1}$ of compost (Table 2). Thus, one month of incubation of composts reduced the count of microorganisms by two orders of magnitude. It is most likely that this phenomenon was related with the type of antagonistic effect between Trichoderma strains and the autochthonous microflora of the composts. This fact was confirmed by the aforementioned research findings. Dual-organism biotic tests conducted in this study proved the inhibitory effect of a few autochthonous strains isolated from both composts on the Trichoderma sp. strains applied in the composts (Tables 5 and 6).

The analysis of the count of Trichoderma sp. isolates (Figures 6 and 7) revealed that the tomato waste compost was a better carrier. It may have been caused by the mycological state of the compost (Table 2), where $T$. atroviride was part of the autochthonous microflora. Apart from that, it may have resulted from the chemical composition of the onion waste compost.

As results from the literature, active compounds of onion (allicin, allicepin, antifungal peptide, sulphur, fistulosin compounds) can destroy fungal cells, decreasing the oxygen uptake, reducing cellular growth, inhibiting the synthesis of lipids, proteins and nucleic acids, changing the lipid profile of the cell membrane and inhibiting the synthesis of the fungal cell wall (Phay et al. 1999, Wang and Ng 2004).

According to Smolińska et al. (2014a) and Cavalcante et al. (2008), agricultural waste can be successfully used as a carrier for fungi of the Trichoderma genus. The expansiveness of these microorganisms is caused by the possibility to use a wide range of compounds as a source of nourishment. According to Smolińska et al. (2014), the capacity of Trichoderma sp. to grow rapidly makes it one of the first fungi to colonise substrates after the process of fumigation.

The data provided in Figure 7 revealed that in both experiments, at the end of the experiment (the second month after the inoculation) the highest statistically significant count of Trichoderma was observed in the tomato waste compost which had simultaneously been inoculated with isolates T1 and T2.

The adaptive capacity of the strains applied individually into composts depended on the type of experiment. In experiment $\mathrm{I}$ isolate $\mathrm{T} 1-T$. atroviride proliferated more intensely, whereas in experiment II - strain T2 - T.harzianum.

The growth and development of Trichoderma sp. was also diversified in the onion waste composts (Figure 4). In experiment $\mathrm{I}$, at both terms the highest statistically significant count of isolate T3 $-T$. harzianum was noted, whereas in experiment II it was strain $\mathrm{T} 1-T$. atroviride.

It is most likely that differences in the proliferation of Trichoderma isolates were caused by the type of interaction with the autochthonous microflora in a particular compost. 


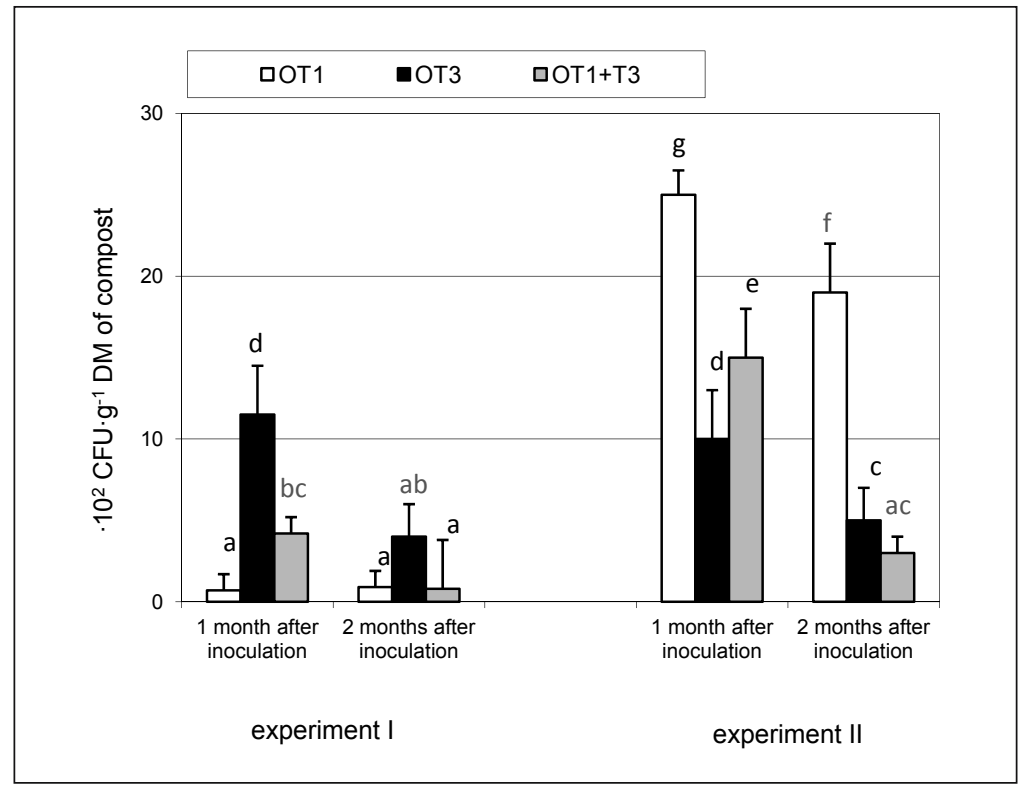

Fig. 6. The changes of Trichoderma sp. in onion composts Explanation as Figure 2

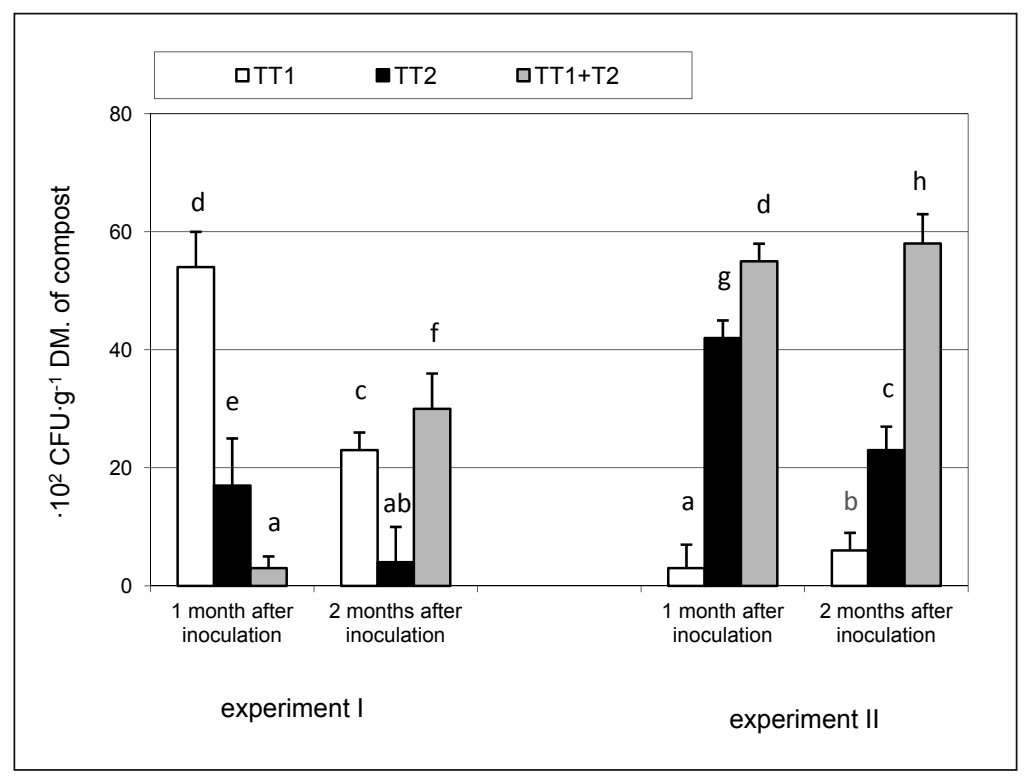

Fig. 7. The changes of Trichoderma sp. in tomato composts Explanation as Figure 3

Table 5. Results of biotic test in dual cultures (tomato compost)

\begin{tabular}{|c|c|c|c|c|c|c|}
\hline \multicolumn{7}{|c|}{ Tomato compost - Experiment I } \\
\hline Isolate & \multicolumn{2}{|c|}{ Penicillium sp. } & \multicolumn{2}{|c|}{ Rhizopus sp. } & \multicolumn{2}{|c|}{ Trichoderma atroviride } \\
\hline T1 & \multicolumn{2}{|c|}{+4} & \multicolumn{2}{|c|}{+8} & \multicolumn{2}{|c|}{0} \\
\hline $\mathrm{T} 2$ & \multicolumn{2}{|c|}{+4} & \multicolumn{2}{|c|}{+6} & \multicolumn{2}{|c|}{0} \\
\hline \multicolumn{7}{|c|}{ Tomato compost - Experiment II } \\
\hline Isolate & $\begin{array}{c}\text { Penicillium sp. } \\
\text { (1) }\end{array}$ & $\begin{array}{c}\text { Penicillium sp. } \\
\text { (2) }\end{array}$ & Mucorsp. & $\begin{array}{l}\text { Rhizopus } \\
\text { nigricans }\end{array}$ & Rhizopus sp. & $\begin{array}{c}\text { Trichoderma } \\
\text { atroviride }\end{array}$ \\
\hline T1 & +8 & +8 & +4 & -4 & +8 & 0 \\
\hline $\mathrm{T} 2$ & +8 & +8 & +4 & +4 & +6 & 0 \\
\hline
\end{tabular}

Explanation: A positive result means that the Trichoderma sp. isolate inhibited the growth of the autochthonous colony; 0 - no inhibition, 8 - total inhibition. 
Table 6. Results of biotic test in dual cultures (onion compost)

\begin{tabular}{|c|c|c|c|c|c|c|c|c|c|c|}
\hline \multicolumn{11}{|c|}{ Onion compost - Experiment I } \\
\hline Isolate & \multicolumn{2}{|c|}{ Penicillium sp. (1) } & \multicolumn{2}{|c|}{ Penicillium sp. (2) } & \multicolumn{2}{|c|}{ Rhizopus sp. } & \multicolumn{2}{|c|}{ Alternaria sp. } & \multicolumn{2}{|c|}{ Mucor sp. } \\
\hline T1 & \multicolumn{2}{|c|}{+8} & \multicolumn{2}{|l|}{+8} & \multicolumn{2}{|r|}{+8} & \multicolumn{2}{|r|}{+8} & \multicolumn{2}{|r|}{+8} \\
\hline T3 & \multicolumn{2}{|l|}{+4} & \multicolumn{2}{|l|}{-6} & \multicolumn{2}{|r|}{+4} & \multicolumn{2}{|r|}{+6} & \multicolumn{2}{|r|}{+4} \\
\hline \multicolumn{11}{|c|}{ Onion compost - Experiment II } \\
\hline Isolate & $\begin{array}{c}\text { Aspergillus } \\
\text { niger }\end{array}$ & $\begin{array}{l}\text { Rhizopus } \\
\text { nigricans }\end{array}$ & $\begin{array}{c}\text { Penicillium sp. } \\
\text { (1) }\end{array}$ & \multicolumn{2}{|c|}{$\begin{array}{c}\text { Penicillium sp. } \\
\text { (2) }\end{array}$} & \multicolumn{2}{|c|}{ Cephalosporium sp. } & $\begin{array}{c}\text { Paecilomyces } \\
\text { variotti }\end{array}$ & Mucorsp. & Alternaria sp. \\
\hline T1 & +4 & -4 & -4 & \multicolumn{2}{|c|}{-4} & \multicolumn{2}{|c|}{+4} & +6 & +8 & +8 \\
\hline T3 & -6 & +4 & +4 & \multicolumn{2}{|c|}{-6} & \multicolumn{2}{|c|}{+4} & +4 & +4 & +6 \\
\hline
\end{tabular}

Explanation as Table 5

Smolińska et al. (2014) also proved differences in the growth and sporulation of Trichoderma sp. isolates in substrates made from vegetable waste (carrot, beetroot, potato) and different types of straw. According to the authors, Trichoderma sp. strains differed in the mycelium growth intensity and sporulation on substrates with identical composition. The applied waste proved to be a good substrate for the growth of Trichoderma sp. Only barley straw added to substrates resulted in inhibition of the growth and sporulation of nearly all of the strains under analysis.

The results of our study let us conclude that the application of organic waste as a carrier for fungi of the Trichoderma genus had two advantages. First of all, it gives a possibility to handle waste which is harmful to the environment. Second of all, the use substrates containing antagonistic Trichoderma fungi will increase the population of useful microorganisms in soil and it will probably translate into the yield of crops.

\section{Conclusions}

1. The highest count of fungi in the onion waste composts was observed in the variant which had simultaneously been inoculated with two strains $\mathrm{T} 1-T$. atroviride and $\mathrm{T} 3-T$. harzianum. The greatest count of moulds in the tomato waste composts was noted in the combination with $\mathrm{T} 2-T$. harzianum strain.

2. The onion waste compost proved to be a good carrier both for strain T1 - T. atroviride, and T3 - T. harzianum (which had been applied separately to the composts).

3. In the tomato waste composts the most intense proliferation of isolates was observed in the variant where two strains had been applied simultaneously, i.e. T1 $-T$. atroviride and T2 - T. harzianum.

4. Penicillum sp. strains were predominant in the onion waste composts. In total they made $84 \%$ of the population of microorganisms in experiment I. In experiment II Penicillium sp. isolates made $54 \%$ of the population, whereas Aspergillus niger and Rhizopus nigricans made 34\%.

5. Penicillium was also the predominant genus in the tomato waste composts, where it amounted to $82 \%$ of the population of microorganisms in experiment I and $44 \%$ in experiment II.

6. The research proved that composted onion and tomato waste, which could be used for vegetable growing, was a good carrier for antagonistic strains of Trichoderma sp. It will increase the yield of crops by inhibiting the growth of plant pathogens.

\section{Acknowledgements}

The research was conducted as part of the project of the National Centre for Research and Development, No. UDA-POIG.01.03.01-00-129/09-09 'Polish Strains of Trichoderma in Plant Protection and Organic Waste Handling'.

\section{References}

Amann, R.I., Krumholz, L. \& Stahl, D.A. (1990). Fluorescent-oligonucleotide probing of whole cells for determinative, phylogenetic and environmental studies in microbiology, Journal of Bacteriology, 172, 2, pp. 762-770.

Bal, U. \& Altintas, S. (2006). A positive side effect from Trichoderma harzianum, the biological control agent: Increased yield in vegetable crops, Journal of Environmental Protection and Ecology, 7, 2, pp. 383-387.

Busko, M., Chełkowski, J., Popiel, D. \& Perkowski, J. (2008). Solid substrate bioassay to evaluate impact of Trichoderma on trichothecene mycotoxin production by Fusarium species, Journal of the Science of Food and Agriculture, 88, 3, pp. 536-541.

Cavalcante, R.S., Lima, H.L.S., Pinto, G.A.S., Gava, C.A.T. \& Rodrigues, S. (2008). Effect of moisture on Trichoderma conidia production on corn and wheat bran by solid state fermentation, Food and Bioprocess Technology, 1, 1, pp. 100-104.

Crop Protection Products Act of 8 March 2013, Official Journal 2013 Pos. 455, pp. 1-53. (in Polish)

Dłużniewska, J. (2004). The influence of incubation temperature on the development and biotic relations between Trichoderma spp. and pathogenic fungi, Acta Scientiarum Polonorum, Agricultura, 3, 2, pp. 257-262. (in Polish)

Domsch, K.H., Gams, W. \& Anderson, T.H. (1993). Compendium of soil fungi, ed., Academic Press, San Francisco 1993.

EU Council Directive 1999/31/CE of 26 April 1999 on Waste Storage, EU Official Journal 1999, L182/1, pp. 228-246.

FAO Statistics,(2008). Productions, crops. (http://faostat.fao.org/ site/567/default.aspx\#ancor (15.02.2008)).

Harman, G.E., Howell, C.R., Viterbo, A., Chet, I. \& Lorito, M. (2004). Trichoderma species-opportunistic, avirulent plant symbionts, Nature Reviews Microbiology, 2, 1, pp. 43-56.

Howell, C.R. (2003). Mechanisms employed by Trichoderma species in the biological control of plant diseases: the history and evolution of current concepts, Plant Disease, 87, 1 pp. 4-10.

Malińska, K., Zabochnicka-Świątek, M. \& Dach, J. (2014). Effects of biochar amendment on ammonia emission during composting of sewage sludge, Ecological Engineering, 7, pp. 474-478.

Mańka, K. (1974). Fungal communities as criterion for estimating the effect of the environment of plant disease in Poland, Zeszyty Problemowe Postęów Nauk Rolniczych, 160, pp. 9-23. (in Polish) 
Martin, J.P. (1950). Use of acid, rose bengal and streptomycin in the plate method for estimating soil fungi, Soil Science, 69, pp. 215-232.

Perek, A., Krzymińska, J. \& Świerczyńska, I. (2013). Comparison of the antagonistic effect of Trichoderma spp. and yeasts on pathogenic Fusarium spp. in in vitro conditions, Journal of Research and Applications in Agricultural Engineering, 58, 4, pp. 99-103. (in Polish)

Phay, N., Higashiyama, T., Tsuji, M., Matsuura, H., Fukushi, Y., Yokota, A. \& Tomita, F. (1999). An antifungal compound from roots of Welsh onion, Phytochemistry, 52, pp. 271-274.

Piegza, M., Stolaś, J., Kancelista, A. \& Witkowska, D. (2009). The influence of fungi of the Trichoderma genus on the growth of pathogenic filamentous fungi in biotic tests on atypical sources of carbon, Acta Scientiarum Polonorum, Biotechnologia, 8, 1, pp. 3-14. (in Polish)

Regulation of the Minister of the Environment on R10 recovery, issued on 20 January 2015, Pos. 132. (in Polish)

Rosalak, M. \& Gworek, B. (2006). The state and assessment of waste handling in Poland, Ochrona Środowiska i Zasobów Naturalnych, 29, pp. 71-84. (in Polish)

Siddiquee, S., Yusof, N.A., Salleh, A.B., Tan, S.G., Bakar, F.A. \& Heng, L.Y. (2010). DNA hybridization based on Trichoderma harzianum gene probe immobilization on self-assembled monolayers on a modified gold electrode, Sensors and Actuators B: Chemical, 147, pp. 198-205.

Skowron, K., Olszewska, H. \& Pawłowska, A. (2011). The effect of composting process on changes in quantity of yeast and mould fungi population, Rocznik Ochrona Środowiska, 3, 1, pp. 1485-1506. (in Polish)

Smolińska, U., Gołębiewska, E., Kowalska, B., Kowalczyk, W. \& Szczech, M. (2014). Waste materials as carriers of antagonistic Trichoderma fungi, Inżynieria i Ochrona Środowiska, 17, 1, pp. 5-20. (in Polish)
Smolińska, U., Kowalska, B., Kowalczyk, W. \& Szczech, M. (2014a). The use of agro-industrial wastes as carriers of Trichoderma fungi in the parsley cultivation, Original Scientia Horticulturae, 179, 24, pp.1-8.

Sołowiej, P. (2007) An example of using a compost prism as a low-temperature source of heat. Department of electrical and power engineering, University of Warmia and Mazury in Olsztyn, Inżynieria Rolnicza, 8, 96, pp. 247-249. (in Polish)

Szczech, M., Staniszek, M., Habdas, H., Uliński, Z. \& Szymański, J. (2008). Trichoderma spp. The cause of green mold on polish mushroom farms, Vegetable Crops Research Bulletin, 69, pp. 105-114.

Wang, H.X. \& Ng, T.B. (2004). Isolation of allicepin, a novel antifungal peptide from onion (Allium cepa) bulbs, Journal of Peptide Science, 10, 3, pp. 173-177.

Wawrzyniak, J. \& Waśkiewicz, A. (2014). Ochratoxin A and citrinin production by Penicillium verrucosum on cereal solid substrates, Food Additives and Contaminants: Part A, 31, 1, pp. 139-148.

Witkowska, D. \& Maj, A. (2002). Production of lytic enzymes by Trichoderma spp. and their effect on the growth of phytopathogenic fungi, Folia Microbiologica, 47, 3, pp. 279-282.

Wojtkowiak-Gębarowska, E. (2006). Mechanisms of controlling soil phytopathogens with fungi of the Trichoderma genus, Postepy Mikrobiologii, 45, 4, pp. 261-273. (in Polish)

Wolna-Maruwka, A., Mocek-Płóciniak, A., Głuchowska, K., Schroeter-Zakrzewska, A., Borowiak, K., Niewiadomska, A., Starzyk, J. \& Dach, J. (2015). Assessment of the influence of composts on microbiological and biochemical parameters of substrates and the morphological traits of scarlet sage, Archives of Environmental Protection, 41(3), pp. 28-38.

Yedidia, I., Srivastava, A.K., Kupalnik, Y. \& Chet, I. (2001). Effect of Trichoderma harzianum on microelement concentrations and increased growth of cucumber plants, Plant and Soil, 235, pp. 235-242.

\title{
Ocena właściwości adaptacyjnych i antagonistycznych szczepów Trichoderma sp. w kompostach z odpadów warzywnych
}

\begin{abstract}
Streszczenie: Przeprowadzone doświadczenie polegało na monitorowaniu liczebności grzybów pleśniowych oraz trzech, wybranych izolatów Trichoderma sp. (T1 - T. atroviride, T2 - T. harzianum, T3 - T. harzianum) w kompostowanych wraz z dodatkami (słoma, obornik świński) odpadach warzywnych (odpady cebulowe i pomidorowe). Dodatkowo celem badań było określenie rodzaju interakcji zachodzącej między autochtonicznymi grzybami wyizolowanymi z kompostów, po ustaniu fazy termofilnej a zastosowanymi szczepami Trichoderma sp. Liczebność mikroorganizmów określano metodą płytkową, a następnie przeprowadzano identyfikację potwierdzającą. Rodzaj interakcji między mikroorganizmami określano stosując metodę Mańki. Najwyższą liczebność grzybów pleśniowych w kompostach wytworzonych na bazie odpadów cebulowych odnotowano w obiekcie zainokulowanym jednocześnie dwoma szczepami T1 $-T$. atroviride oraz T3 $-T$. harzianum. $\mathrm{Z}$ kolei w kompostach pomidorowych, w kombinacji z dodatkiem szczepu T2 - T. harzianum. Przeprowadzona identyfikacja mikroskopowa wykazała, że w kompostowanych odpadach cebulowych dominowały szczepy Penicillum sp., Rhizopus sp., Alternaria sp., Mucor sp. Z kolei w odpadach pomidorowych dominującym rodzajem okazał się Penicillum., a następnie Rhizopus. Przeprowadzony test na antagonizm wykazał, ponadto inhibicyjne wpływ izolatów Trichoderma w stosunku do większości autochtonicznych szczepów grzybów pleśniowych Komposty wytworzone z odpadów pomidorowych okazały się lepszym podłożem dla wzrostu i rozwoju izolatów Trichoderma sp. Wyniki uzyskane w pracy wskazują, że odpady warzywne można wykorzystać w rolnictwie jako nośniki mikroorganizmów antagonistycznych.
\end{abstract}

